\title{
Cretaceous to Holocene forearc evolution in Japan and its implication to crustal dynamics
}

The forearc tectonic evolution of Japan since Cretaceous time has revealed three important tectonic processes: the formation of a sedimentary accretionary prism, crustal accretion and imbrication, and subduction erosion. The accretion of sediments seems to have been controlled mainly by the input of sediment into a trench, as has been documented in the Shimanto Belt and the Nankai accretionary prism. Crustal accretion and imbrication have been taking place at a collision zone between arcs. These processes are associated with the collision and subduction of hot and rheologically weak lithosphere of the arc. Subduction erosion of forearc slopes has been documented in the Japan Trench in relation to the subduction of graben features and seamounts.

The most important inference drawn from the forearc evolution of the Japanese islands is that the majority of the continental crust in these island arcs was formed by the accretion of sediments and the intrusion of granites and that a part of this was eroded later and subducted. This process offers a global implication as to how continental crust has evolved throughout the Earth's history.

\section{Introduction}

The Cretaceous to Cenozoic tectonic evolution of the forearc areas of the Japanese arc and trench systems has been controlled dominantly by three tectonic processes: (1) the formation of accretionary prisms that are made up sedimentary sequences composed of material scraped from the subducting oceanic plate and tectonic slivers of oceanic materials, (2) the crustal accretion and imbrication at a collision zone between arcs, and (3) the subduction erosion of forearc slopes. The first process is best documented in the southwestern Japan arc, where it is represented by the development of the Cretaceous to Tertiary Shimanto accretionary prism and by the current accretion in the Nankai Trough (Taira, 1985; Ogawa, 1985; Taira and others, 1988) (fig. 1). The second process has been in progress since the middle Miocene at a collision boundary between the IzuBonin arc and the Honshu arc (Ogawa and others, 1985; Amano, 1986). The third process has been demonstrated by recent investigation of the sea floor by submersibles and SeaBeam mapping, especially during the Japanese-French Kaiko Project, which has revealed large-scale gravity collapse of the forearc slope in the Japan Trench (Cadet and others, 1987; Von Huene and Lallemand, 1990; Kobayashi and others, 1991).

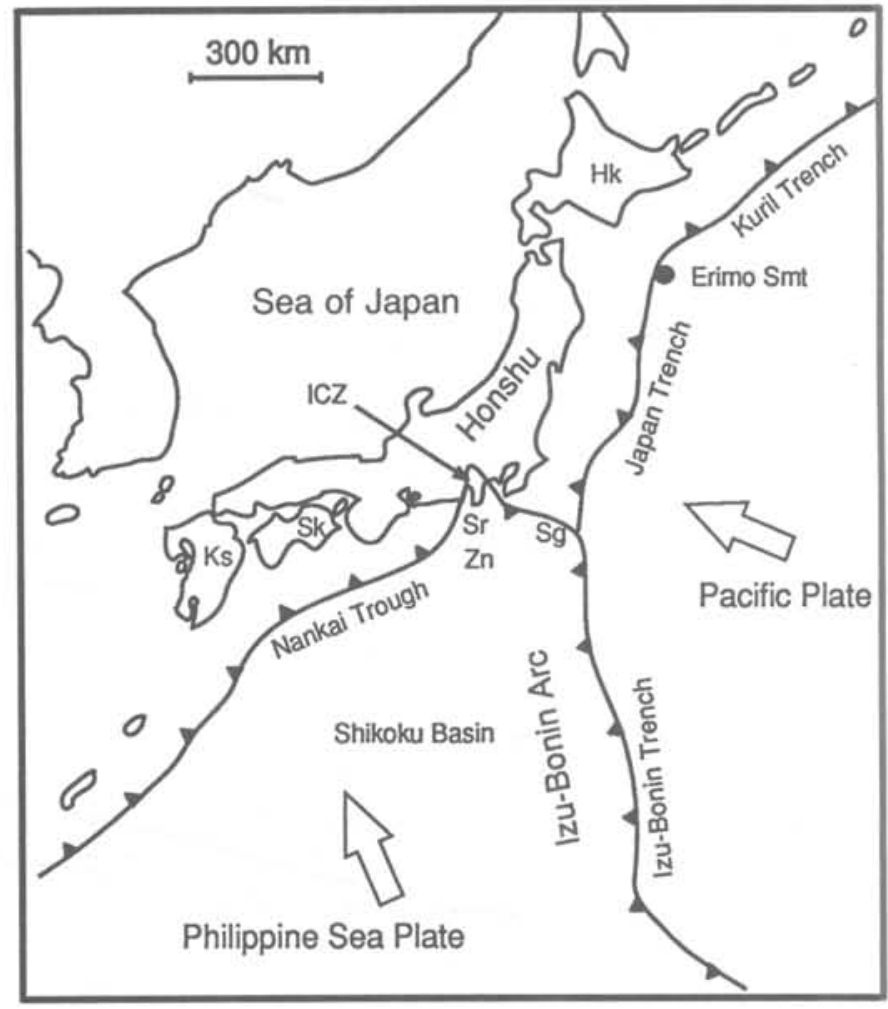

Figure 1.-Present framework of the arc-trench systems around the Japanese islands. Arrow shows direction of plate movement. Barbed line shows the subduction zone. Abbreviations: ICZ, Izu collision zone; $\mathrm{Sr}$, Suruga Trough; $\mathrm{Zn}$, Zenisu Ridge; Sg, Sagami Trough; Ks, Kyushu; Sk, Shikoku; Hk, Hokkaido; Erimo Smt, Erimo Seamount.

In this brief account, we review these three important tectonic processes in the forearcs and trenches of the Japanese arc and trench systems. In addition, we discuss their implications to crustal evolution in general.

\section{Evolution of the Shimanto accretionary prism}

During most of Mesozoic to early Miocene time, a continental arc at the eastern margin of the Asian continent probably extended from southern China to the northeastern Siberian region (Taira and others, 1989) (fig. 2). Most of the basement rocks of the present-day Japanese arc were formed during this period of subduction tectonism, 

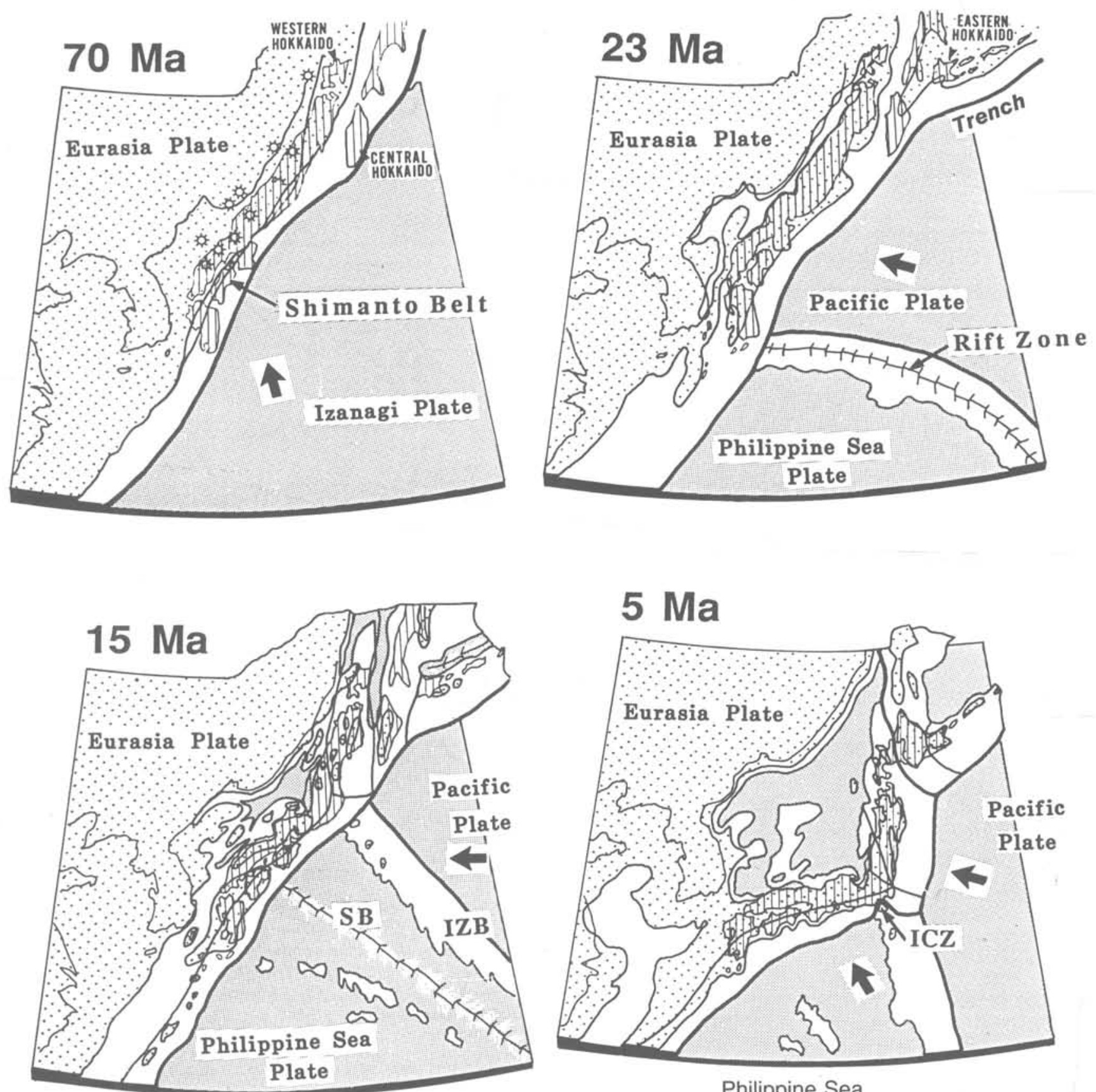

Philippine Sea

Plate

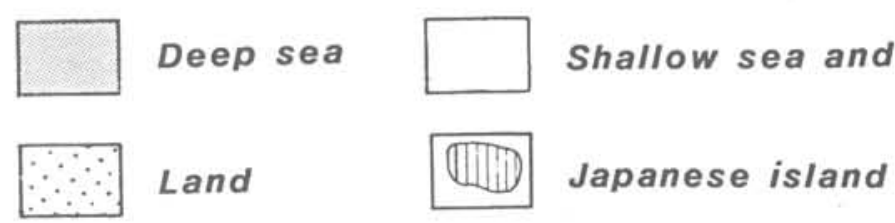

Figure 2.-Tectonic evolution of the Japanese islands since the Late Cretaceous (taken from Taira and others, 1989). Arrow shows direction of plate movement. Heavy line is the subduction zone. Abbreviations: SB, Shikoku Basin; IZB, Izu-Bonin arc; ICZ, Izu collision zone. 
which included both the formation of accretionary prisms and the intrusion of granites (Taira and others, 1989). The Cretaceous and early Miocene part of the accretionary prism is called the Shimanto Beit (see Taira and Ogawa, 1988, for a general introduction). Extending from central Honshu to the Ryukyu Islands, the belt is about $1,800 \mathrm{~km}$ along its strike and has a maximum width of $100 \mathrm{~km}$, so it is the largest structural element of the Japanese islands.

The Shimanto Belt is one of the most studied accretionary prisms in the world. The age of the subducted oceanic plate, the nature of the oceanic and infilled-trench sedimentary sequence, and the style of deformation are well constrained by the large amount of data that has been collected.

The Shimanto Belt is composed of two main lithologies: a relatively coherent turbidite sequence and a highly deformed mélange belt. These lithologies occur in a repeated fashion that is similar to the structure of a fold and thrust belt, and they systematically become younger oceanward. A key to the understanding of the origin of the Shimanto Belt lies in the mélange belt, which includes tectonic slivers of basaltic pillow lavas, nanno-ooze limestones, radiolarian cherts, red pelagic shales, and varicolored hemipelagic shales and volcanic ash layers that are dispersed in a highly sheared argillaceous matrix. Considerable effort, mainly based on radiolarian biostratigraphy, has been carried out in order to determine the geologic age of these lithologies. By dating the infilled-trench sedimentary sequence and the pelagic and hemipelagic sediments, we have been able to reconstruct the trench stratigraphy throughout the evolution of the Shimanto Belt
The best documented example of plate stratigraphy has been obtained from the island of Shikoku (Taira and others, 1988) (fig. 3). Here, dating of Cretaceous mélange lithologies by the use of micro fossils indicates that nannofossil-bearing limestone and radiolarian cherts are Valanginian $(130 \mathrm{Ma})$ to Cenomanian $(100 \mathrm{Ma})$ in age. varicolored shales are Coniacian to Santonian (80 Ma), and the argillaceous mélange matrix is Campanian (70 Ma). The adjacent coherent turbidite unit (trench deposits) also dates from the Campa nian. Paleomagnetic analysis of these rocks has revealed that Valan ginian pillow lavas and nannofossil limestones were formed at equa torial latitudes, whereas the coherent turbidite units of Campanian age (70 Ma) were deposited more or less at their current position of latitude $\left(30^{\circ}\right.$ N.) (Kodama and others, 1983). Thus, we think that an ocean floor originated at the equatorial latitude at $130 \mathrm{Ma}$, that $\mathrm{i}$ : moved at least $3,000 \mathrm{~km}$, and that it then was subducted at $70 \mathrm{Ma}$ The dating of mélange lithologies throughout the Shimanto Belt has revealed a systematic change of oceanic-plate stratigraphy through time: a time progressive decrease of age difference between the basa! pelagic unit and the sedimentary sequence in the trench. This suggests that the juvenile oceanic lithosphere was subducted during most of Paleogene, which constrained the plate reconstruction of the western Pacific Ocean to Cretaceous to Tertiary time.

On the basis of such a firm foundation for tectonic evolution more detailed structural analyses are being done for the Shimanto Belt. These analyses include the study of the structural evolution in relation to plate kinematics (Nishi, 1988; DiTullio and Byrne, 1990). mélange fabrics (Kimura and Mukai, 1989; Kano and others, 1991).

\begin{tabular}{|c|c|c|c|c|c|c|c|}
\hline \multicolumn{2}{|c|}{ AGE } & \multirow{2}{*}{$\begin{array}{l}\text { LITHOLOGIC } \\
\text { COLUMN }\end{array}$} & \multirow{2}{*}{$\begin{array}{l}\text { LITHOFACIES } \\
\text { (thickness) }\end{array}$} & \multirow{2}{*}{$\begin{array}{l}\text { QUARTZ } \\
\text { GRAIN }\end{array}$} & \multirow{2}{*}{$\begin{array}{l}\text { ACIDIC } \\
\text { TUFF }\end{array}$} & \multirow{2}{*}{ PALEOENVIRONMENT } & \multirow{2}{*}{$\begin{array}{l}\text { PALE0- } \\
\text { LATITUDE }\end{array}$} \\
\hline Stage & Ma & & & & & & \\
\hline \multirow[t]{2}{*}{ Camp. } & 70 & & Sandy flysch $(1000 \mathrm{~m})$ & \multirow{4}{*}{$\begin{array}{c}>100 \\
30\end{array}$} & \multirow{4}{*}{ 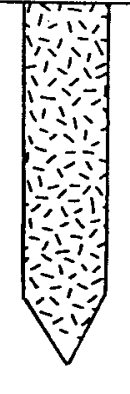 } & $\begin{array}{l}\text { Trench } \\
\text { Channel turbidite }\end{array}$ & \multirow{4}{*}{ 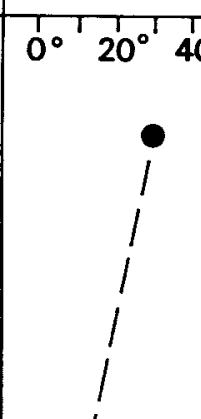 } \\
\hline & & 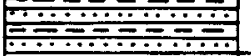 & Muddy flysch matrix) & & & Overbank turbidite & \\
\hline \multirow{4}{*}{$\begin{array}{l}\text { Sant. } \\
\text { Coniac } \\
\text { Turon. } \\
\text { Cenom. } \\
\text { Alb. } \\
\text { Apt. } \\
\text { Barr. } \\
\text { Haut. }\end{array}$} & 80 & 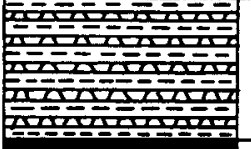 & $\begin{array}{l}\text { Varicolored shale } \\
\qquad(100 \mathrm{~m})\end{array}$ & & & $\begin{array}{l}\text { Hemipelagic mud } \\
\text { and acidic tuff }\end{array}$ & \\
\hline & 90 & & Red shale $(5 \mathrm{~m})$ & & & Pelagic clay & \\
\hline & $\begin{array}{l}100 \\
110 \\
120\end{array}$ & & $\begin{array}{l}\text { (with red shale) } \\
\text { Bedded chert }(50 \mathrm{~m}) \\
\text { (with nanno ls) } \\
\end{array}$ & \multirow[t]{4}{*}{$\begin{array}{l}\text { Mean } \\
\text { size, } \\
\text { in } \\
\text { microns }\end{array}$} & & Radiolarian ooze & ${ }_{1}^{1}$ \\
\hline & & 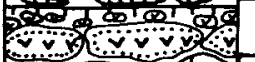 & Pillow lava & & & Oceanic basalt & $\gamma$ \\
\hline \multirow[t]{2}{*}{ Valang } & 130 & 空工SII & Nanno limestone $(1 \mathrm{~m})$ & & & Nanno ooze & \\
\hline & 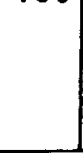 & 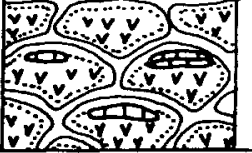 & Pillow lava & & & Oceanic basalt & \\
\hline
\end{tabular}

Figure 3. - Reconstructed plate stratigraphy from mélange belt of the Shimanto Belt, island of Shikoku, Japan (taken from Taira and others, 1988). Abbreviations: Valang, Valanginian; Haut., Hauterivian; Barr., Barremian; Apt., Aptian; Alb., Albian; Cenom., Cenomanian; Turon., Turonian; Coniac, Coniacian; Sant., Santonian; Camp., Campanian; ls, limestone. 
duplex structure (Murata, 1991), effect of ridge subduction (Hibbard and Karig, 1990), nature of underplated basaltic rocks (Ogawa and Taniguchi, 1989), and thermal evolution (Komatsu and others, 1991). We envision that such continuous efforts on the study of the Shimanto Belt will set a standard for geological, geochemical, and geophysical models for the evolution of an accretionary prism.

The subduction at the continental margin of eastern Asia from Cretaceous to Paleogene time was followed by successive events of dramatic tectonic evolution: the eastward migration of the Izu-Bonin arc and the spreading of the Shikoku Basin, the rotation of the southwestern and northeastern Japan arcs and the spreading of the Sea of Japan, and the subsequent collision of the Izu-Bonin arc against Honshu (fig. 2).

\section{Nankai accretionary prism}

The present-day subduction zone of the Shikoku Basin is represented by the Nankai Trough, where we can observe the development of a typical accretionary prism. A large amount of data on this prism has resulted from concentrated marine geological and geophysical investigations, such as drilling done by the Deep Sea Drilling Project and the Ocean Drilling Project (ODP) (Kagami and others, 1985; Taira and others, 1991), SeaBeam mapping and submersible diving carried out during the Japanese-French Kaiko Project (Kaiko I Research Group, 1986; Kobayashi and others, 1990; Le Pichon and others, 1990), the two-ship seismic experiments done by Japan and the United States (Moore and others, 1990; Stoffa and others, in press), and the IZANAGI long-range side-scan survey (Ashi and others, 1990).

Basically, two layers of sediments are being subducted below the forearc in the Nankai Trough: an upper turbidite sequence and a lower hemipelagic sequence that together form a 1-2-km-thick pile of sediments (fig. 4A). The turbidites in Nankai were supplied westward from the Suruga Trough drainage area, especially from the Fuji River. This sediment transport avenue is the result of the arc-arc collision between the Izu-Bonin arc and the Honshu arc (Taira and Niitsuma, 1985).

The results of ODP Leg 131, which penetrated the entire sedimentary sequence from the toe of the prism to the basaltic basement, characterized the nature of the décollement (Taira and others, 1991). We found a sharp offset of physical properties. The porosity above the décollement was 30 percent, and it increased to 40 percent below the 19-m-thick décollement zone. The sediments above the décollement are highly deformed because of the nearly horizontal compression oriented in a northwest-southeast direction, whereas the sediment below the décollement was little deformed. These observations indicate that the basal décollement of the Nankai accretionary prism is an overpressured zone that acts as a seal and prohibits drainage of the underthrust sequence. In addition, the basal décollement is a distinct stress discontinuity

Submersible diving carried out during the Kaiko Project and the Kaiko-Nankai Project in the eastern Nankai Trough have revealed the widespread occurrence of seepage-related biological communities that are represented by the giant clam Calyptogena, which is found together with calcareous cemented clasts. Detailed measurements near the surface of the geothermal gradient in the biological communities were interpreted to show a large flux of methane-rich porewater, which cannot be explained easily by dewatering of the underlying sediment (Le Pichon and others, 1990). Le Pichon and others (1990) have proposed the existence of shallow, near-surface convection as a way of accounting for this extra expulsion of water. The role of fluids in the structural and geochemical evolution of an accretionary prism is an important unsolved problem, and the Nankai Trough provides one of the best fields for such investigation.

\section{Arc-arc collision and crustal imbrication}

After the opening of the Shikoku Basin, the Izu-Bonin arc collided against the island of Honshu and produced a zone of repeated slices of arc crust and infilled-trough sequence that is called the Izu collision zone (fig. 1) (Soh and others, 1991). The Izu collision zone has been an active collision and accretion zone for several million years and has undergone progressive tectonic deformation that probably was initiated during the opening of the Sea of Japan at about $15 \mathrm{Ma}$ in the middle Miocene (Taira and others, 1989). This collisionrelated deformation has resulted in the formation of thrust-bound tectonic crustal segments that range up to several tens of kilometers in size and consist of volcanic and volcanjclastic successions from the Izu-Bonin arc.

Relatively short lived foreland basins, which are filled by an overall upward-coarsening sedimentary sequence, have developed along the boundary thrust faults. This sedimentary sequence is represented by hemipelagic, deep-water shales at the base that are intercalated with volcaniclastic and turbidite debris-flow deposits in the middle and have fan-delta to delta-plain fluvial deposits at the top. The overall thickness of the sequence reaches more than $5 \mathrm{~km}$ and was deposited over a period of a million years. The basin-filling sediments tend to be younger in age progressively from north to south, and they range from middle Miocene to Pleistocene. The thrust movements that generated the foreland basins are thought to have shifted southward as time passed, which we interpret as the incremental migration of the plate boundary that was caused by the incorporation of the frontal segment of the Izu-Bonin arc into the Honshu arc (Taira and others, 1989). The forearc part of the IzuBonin arc was accreted along the Sagami Trough and formed an accretionary complex called the Miura Group (Ogawa and others, 1985; Ogawa and Taniguchi, 1988; Soh and others, 1991), which represents one of the rare examples of a young and shallow-level accretionary prism that is exposed on land.

Collision-related deformation has extended beyond the Izu collision zone to the nearby Philippine Sea plate in the northern Shikoku Basin (fig. 1). A linear topographic high, the Zenisu Ridge, extends from the northeastern Shikoku Basin to the Izu-Bonin arc a few tens of kilometers seaward of the Nankai Trough. The ridge formed from the rupture caused by the uplift of the Shikoku Basin oceanic crust as a result of intraplate compressive tectonism (Le Pichon and others, 1987).

The Izu collision zone provided a unique tectonic setting for the collision and subduction of hot and rheologically weak lithosphere (Lallemant and others, 1989). Crustal imbrication and the infilling of foreland basins produced a repeated succession of volcanic piles and sediment. These lithologies are quite different from those of the sediment-dominated accretionary prisms in the Shimanto Belt and the Nankai Trough. The documentation of these two contrasting accretionary processes, sediment accretion in contrast to crustal accretion, is an important result of Cretaceous to Cenozoic accretionary tectonism in Japan.

\section{Subduction erosion in the Japan Trench}

The Japan Trench is 7-8 $\mathrm{km}$ deep and is sediment starved. The seaward slope of the trench is characterized by well-developed halfgraben structures on the subducting ocean plate (fig. 4B). 


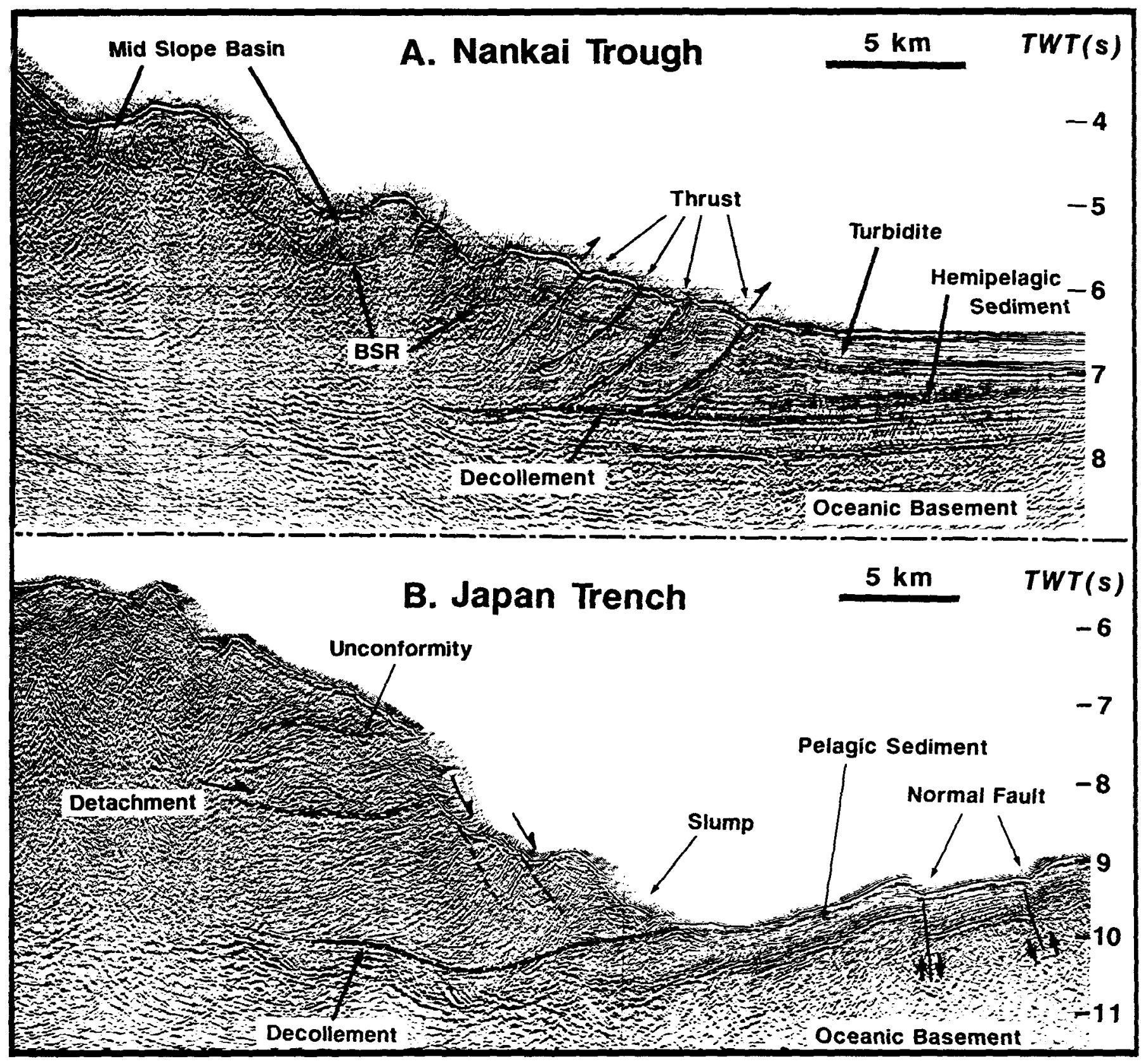

Figure 4. - Seismic-reflection profiles from the Nankai Trough (A) and the Japan Trench (B) (taken from Taira and others, 1990). Abbreviations: TWT(s), two-way traveltime, in seconds; BSR, bottom simulating reflector (gas hydrate phase transition).

The landward slope of the trench is steep, the mean slope angle being $7^{\circ}$, and it commonly has a steeper upper slope that is characterized by benched topography. SeaBeam topographic mapping shows that the landward slope of the Japan Trench is dominated by large-scale gravity collapse (Cadet and others, 1987; Kobayashi and others, 1991). The topography is characterized by steep concave scours, large blocks of slope material, and a debris apron on the trench floor.
The most spectacular examples of the landward topography of the Japan Trench are associated with the subduction of a seamount near the junction of the Japan and Kuril Trenches (figs. 1 and 5). The inner trench wall in this area shows signs of a seamount that has been subject to indentation and gravity failure. A large embayment that has enormous scours is observed to the north of the Erimo Seamount. which is part of a seamount train that is approaching the trench axis. Yamazaki and Okamura (1989) investigated this area further by using 


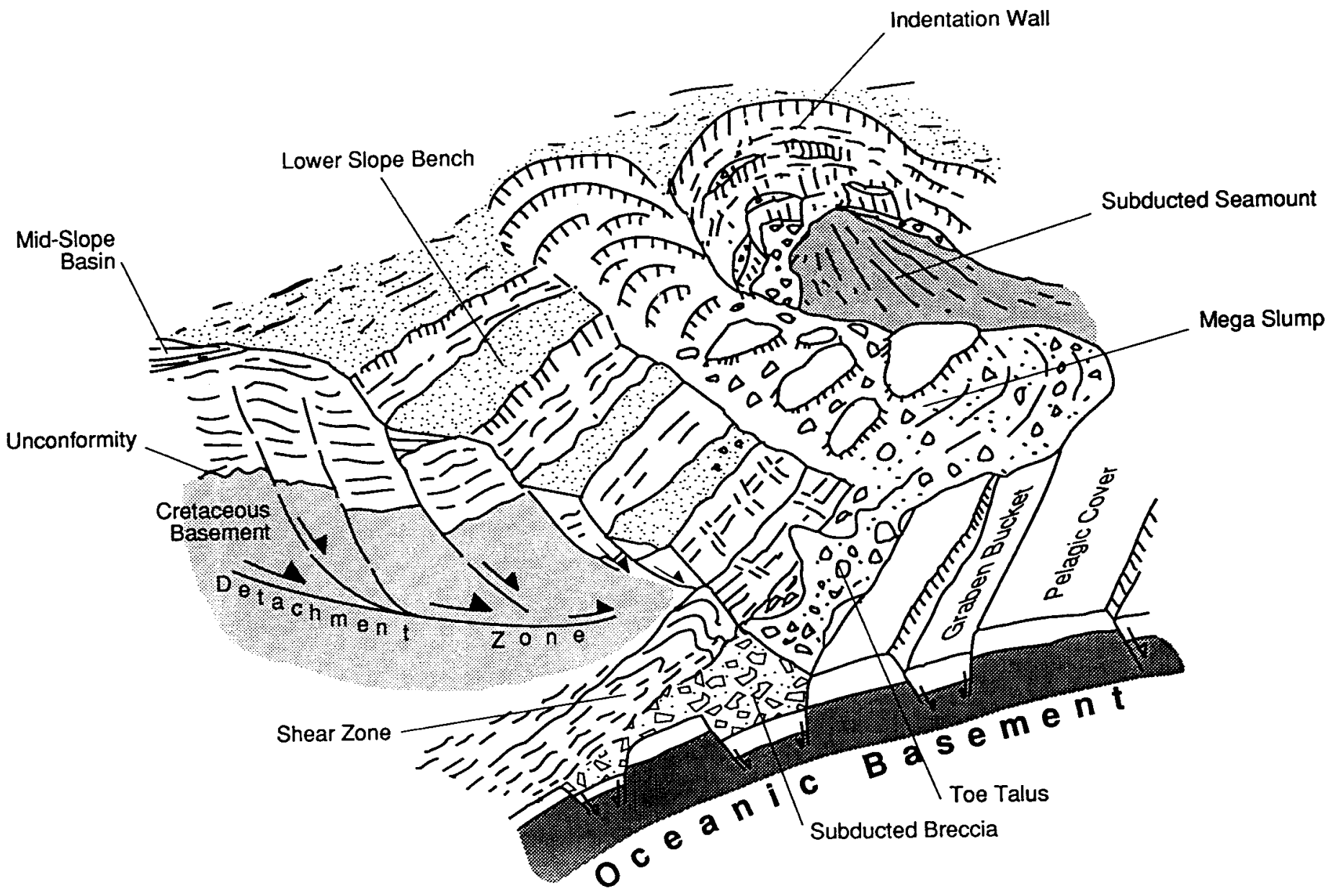

Figure 5.-Schematic illustration of forearc erosion processes observed in the Japan Trench (taken from Taira and others, 1990).

magnetic-anomaly studies, and they suggested that a seamount of about the same size as Erimo Seamount is buried beneath the irregular topography that has been created partly by slope failure. Southeast of Erimo. the inner wall of the Japan Trench comprises a series of crescent-shaped escarpments and intervening hummocky terrain, and it has lobate topography that is indicative of a huge submarine landslide complex. The slide, $50 \mathrm{~km}$ by $40 \mathrm{~km}$, probably resulted from seamount subduction (Fujioka and Taira, 1989; Taira and others. 1990).

These studies reveal that the lower part of the landward slope of the Japan Trench is mechanically very weak, probably owing to overpressuring. and is, therefore, subject to frequent, massive gravity failure (Von Huene and Culotta, 1989). The slump debris and collapsed material filled the graben depression, which was brought eventually to the subduction zone. The seismic images suggest that the décollement of the plate boundary developed within the upper part of the trench's sedimentary sequence and that most of the sediment filling the graben seems to have been subducted deeper (see figure $4 \mathrm{~B}$ ).

The subduction erosion of the forearc slopes seems to have persisted since Miocene time, as documented by the large subsidence of the forearc region (Von Huene and others, 1982). The material removed by this process is estimated on the basis of model calculations to be about $50 \mathrm{~km}^{2} / \mathrm{m} . \mathrm{y}$. (Von Huene and Lallemand, 1990).

\section{Implications to crustal dynamics}

The forearc tectonic history observed in Japan from Cretaceous to Cenozoic time can be classified as follows:

(1) The accretion of thick sedimentary sequences and the development of accretionary prisms represented by the Cretaceous to Paleogene history of the Shimanto Belt and the present-day Nankai Trough.

(2) Crustal accretion and imbrication in relation to the collision and subduction of the island arc after the Miocene.

(3) Subduction erosion of the forearc in the Japan Trench after the Miocene.

We would like to point out that the majority of the crust in the Japanese island arcs, which shows a crustal profile as thick as $40 \mathrm{~km}$, is composed dominantly of accretionary prism sediments and granitic 
intrusive rocks. We suggest that sediment accretion is a fundamental process for the growth of continental crust.

The cause of crustal accretion and tectonic erosion can be related to the mode of plate subduction, which shows different thermal and rheological properties. Subduction of hot and rheologically weak lithosphere, such as that found in an island arc, causes crustal imbrication. Subduction of mature and cold lithosphere, along with the development of horst and graben structures and sediment starvation, enhances forearc erosion and sediment subduction.

Such tectonic processes as these should be reconsidered in a time-progressive manner with respect to the Earth's thermal history: subduction of "hot" lithosphere in Archean time and subduction of cooler lithosphere in Phanerozoic time. Crustal imbrication in the Izu collision zone can be viewed as a direct analogy to the subduction tectonism of the early Earth. This has important implications regarding the origin of Archean crust, such as greenstone-granite terranes (Hoffman, 1991; Taira and others, in press). On the other hand, tectonic erosion and sediment subduction in the Japan Trench can be interpreted as characteristic of subduction tectonism in later phases of the Earth's history.

Sediment accretion, as documented in the Shimanto Belt and the Nankai Trough, is controlled mainly by the input of sediment into the trench. Thus, this process could have occurred throughout the history of the Earth. This general inference further implies that the material put into the asthenosphere should have changed throughout the Earth's history. Most of the upper crustal materials would have been delaminated and imbricated at the convergent boundary in the early Earth. On the other hand, in a later phase of the Earth's history, plate subduction could have conveyed a relatively larger proportion of supracrustal materials to the mantle. Such a gross change in subduction tectonism and the cycle of materials through the course of the evolution of the Earth should have affected the nature of magmatism, mantle composition, and heterogeneity of the mantle. We conclude that the tectonic history of subduction observed in the Japanese arc systems can be related to global crustal dynamics and the evolution of the Earth, although further detailed study is necessary to assess this important issue.

\section{References}

Amano, K., 1986, Southern Fossa Magna as multiple collision belt: Earth Monthly (Chikyu), v. 8, p. 581-585. [In Japanese.]

Ashi, J., Tokuyama, H., and Taira, A., 1990, Structure of the Nankai Trough accretionary prism revealed by IZANAGI oceanfloor imaging sonar system: Journal of the Sedimentological Society of Japan, v. 33, p. 43-48. [In Japanese, English abstract.]

Cadet, J.-P., Kobayashi, K., and others, 1987, The Japan Trench and its juncture with the Kuril Trench: Cruise results of the Kaiko Project, Leg 3: Earth and Planetary Science Letters, v. 83, p. 267-284.

DiTullio, L.D., and Byme, T.B., 1990, Deformation in the shallow levels of an accretionary prism: The Eocene Shimanto Belt of southwest Japan: Geological Society of America Bulletin, v. 102, p. 1420-1438.

Fujioka, K., and Taira, A., 1989, Tectono-sedimentary settings of seep biological communities-A synthesis from the Japanese subduction zones, in Taira, A., and Masuda, F., eds., Sedimentary facies in the active plate margin: Tokyo, Terra Scientific Publishing Company, p. $577-602$.

Hibbard, J.P., and Karig, D., 1990, Structural and magmatic responses to spreading ridge subduction; an example from southwest Japan: Tectonics, v. 9, p. 207-230.

Hoffman, P.F., 1991, On accretion of granite-greenstone terranes, in Robert, F., Sheahan, P., and Green, S., eds., Nuna Conference on Greenstone Gold and Crustal Evolution, Val D'or, Quebec, Canada, 1990: Geological Association of Canada.
Kagami, H., Karig, D.E., and others, 1985, Initial reports of the Deep Sea Drilling Project, v. 87: Washington, D.C., U.S. Government Printing Office, $985 \mathrm{p}$

Kaiko I Research Group, 1986, Topography and structure of trenches around Japan--Data atlas of Franco-Japanese Kaiko Project, phase J: Tokyo, University of Tokyo Press, $305 \mathrm{p}$.

Kano, K., Nakaji, M., and Takeuchi, S., 1991, Asymmetrical mélange fabrics as possible indicators of the convergent direction of plates: A case study from the Shimanto Belt of the Akaishi Mountains, central Japan: Tectonophysics, v. 185, p. 375-388.

Kimura, G., and Mukai, A., 1989. Underplated mélange unit: An example from the Shimanto Belt, southwest Japan: Earth Monthly (Chikyu), v 11, p. 697-709. [In Japanese.]

Kobayashi, K., and shipboard scientific party, 1991, Preliminary report of the Hakuho Maru Cruise KH90-1: Ocean Research Institute, University of Tokyo, $174 \mathrm{p}$.

Kobayashi, K., Le Pichon, X.. and Kaiko-Nankai participating scientists. 1990, General description of the Kaiko-Nankai project [abs.], in Cadet. J.-P., and Le Pichon, X., eds., International Conference on Fluids in Subduction Zones, Paris, 1990: Paris, Université Pierre et Marie Curie. p. 7.

Kodama, K., Taira, A., Okamura, M., and Saito, Y, 1983, Paleomagne tism of the Shimanto Belt in Shikoku, southwest Japan, in Hashimoto. M., and Uyeda, S., eds., Accretion tectonics in the circum-Pacific regions: Tokyo, Terra Scientific Publishing Company, p. 146-165.

Komatsu, M., Shiraishi, R., Matsuo, M., and Tanaka, R., 1991, High T/P metamorphism in the lower part of the Shimanto Belt during middle Miocene time [abs.]: Geological Society of Japan, Annual Meeting. 98th, Matsuyama, 1991, p. 34-35. [In Japanese.]

Lallemant, S., Chamot-Rooke, N., Le Pichon, X., and Rangin, C., 1989. Zenisu Ridge: A deep intraoceanic thrust related to subduction off southwest Japan: Tectonophysics, v. 160, p. 151-174.

Le Pichon, X., Iiyama, T., and others, 1987, Nankai Trough and Zenisu Ridge: A deep-sea submersible survey: Earth and Planetary Science Letters, v. 83 , p. $285-299$

Le Pichon, X., and the Kaiko-Nankai scientific crew, 1990, Fluid venting in easternmost Nankai accretionary prism based on Kaiko-Nankai cruise results [abs.], in Cadet, J.-P., and Le Pichon, X., eds., International Conference on Fluids in Subduction Zones, Paris, 1990: Paris. Université Pierre et Marie Curie, p. 8-10

Moore, G.F., Shipley, T.H., Stoffa, P.L., Karig, D.E., Taira, A. Kuramoto, S., Tokuyama, H., and Suyehiro, K., 1990, Structure of the Nankai Trough accretionary zone from multichannel seismic reflection data: Journal of Geophysical Research, v. 95, p. 8753-8765.

Murata, A., 1991, Duplex structure of the Uchinohae Formation in the Shimanto terrane, Kyushu, southwest Japan: Journal of the Geological Society of Japan, v. 97, p. 39-52. [In Japanese, English abstract.]

Nishi, H., 1988, Structural analysis of part of the Shimanto aceretionary complex, Kyushu, Japan, based on planktonic foraminiferal zonation: Modern Geology, v. 12, p. 47-69.

Ogawa, Y., 1985, Variety of subduction and accretionary processes in Cretaceous to Recent plate boundaries around southwest and central Japan: Tectonophysics, v. 112, p. 493-518.

Ogawa, Y., Horiuchi, K., Taniguchi, H., and Naka, J., 1985, Collision of the Izu arc with Honshu and the effects of oblique subduction in the Miura-Boso peninsulas: Tectonophysics, v. 119, p. 349-379.

Ogawa, Y., and Taniguchi, H., 1988, Geology and tectonics of the Miura Boso peninsulas and the adjacent area: Modern Geology, v. 12 p. $147-168$

- 1989, Origin and emplacement of basaltic rocks in the accretionary complexes in SW Japan: Ofioliti, v. 14, p. 177-193.

Soh, W., Pickering, K.T., Taira, A., and Tokuyama, H., 1991, Basin evolution in the arc-arc Izu Collision Zone. Mio-Pliocene Miura Group. central Japan: Journal of the Geological Society [London], v. 148, p. 317-330.

Stoffa, P.L., Wood, W.T., Shipley, T.H., Moore, G.F., Nishiyama, E. Botelho, M.A.B., Taira, A., Tokuyama. H., and Suyehiro, K.. in press, Deep water high resolution expanding spread and split-spread marine seismic profiles in the Nankai Trough: Journal of Geophysical Research. 
Taira, A., 1985, Sedimentary evolution of Shikoku subduction zone: The Shimanto Belt and Nankai Trough, in Nasu, N., and others, eds., Formation of active ocean margins: Tokyo, Terra Scientific Publishing Company, p. 835-851.

Taira, A., Ashi, J., Kuramoto, S., Soh, W.. Nishiyama, E., Tokuyama, H., Fujioka, K., and Suyehiro, K., 1990, Accretion versus erosion in forearc tectonics - A case study from the Nankai Trough and the Japan Trench, in Wang, P., Lao, Q., and He, Q., eds., International Conference on Asian Marine Geology, 1st, Shanghai, 1988. Proceedings: Beijing, China Ocean Press, p. 39-53.

Taira, A., Hill, I.A., and others, 1991, Proceedings of the Ocean Drilling Program, initial reports, v. 131: College Station, Texas, Texas A\&M University, $306 \mathrm{p}$.

Taira, A., Katto, J., Tashiro, M., Okamura, M., and Kodama, K., 1988, The Shimanto Belt in Shikoku, Japan-Evolution of Cretaceous to Miocene accretionary prism: Modern Geology, v. 12, p. 5-46.

Taira, A., and Niitsuma, N., 1985, Turbidite sedimentation in the Nankai Trough as interpreted from magnetic fabric, grain size, and detrital model analyses, in Kagami, H., Karig, D.E., and others, Initial reports of the Deep Sea Drilling Project, v. 87: Washington, D.C., U.S. Government Printing Office, p. 611-632.

Taira, A., and Ogawa, Y., eds., 1988, The Shimanto Belt, Southwest Japan-Studies on the evolution of an accretionary prism: Modern Geology, v. 12, 542 p.

Taira, A., Pickering, K.T., Windley, B.F., and Soh, W., in press, Accretion of Japanese island arcs and implications for the origin of Archean greenstone belts: Tectonics.

Taira, A., Tokuyama, H., and Soh, W., 1989, Accretion tectonics and evolution of Japan, in Ben-Avraham, Z., ed., The evolution of the Pacific Ocean margins: Oxford, Oxford University Press, p. 100-123.

Von Huene, R., and Culotta, R., 1989, Tectonic erosion at the front of the Japan Trench convergent margin: Tectonophysics, v. 160, p. 75-90.

Von Huene, R., and Lallemand, S., 1990, Tectonic erosion along the Japan and Peru convergent margins: Geological Society of America Bulletin, v. 102, p. 704-720.

Von Huene, R., Langseth, M.G., Nasu, N., and Okada, H., 1982, A summary of Cenozoic tectonic history along the IPOD Japan Trench transect: Geological Society of America Bulletin, v. 93, p. 829-846.

Yamazaki, T., and Okamura, Y., 1989, Subducting seamounts and deformation of overriding forearc wedges around Japan: Tectonophysics, v. 160 , p. $207-229$.

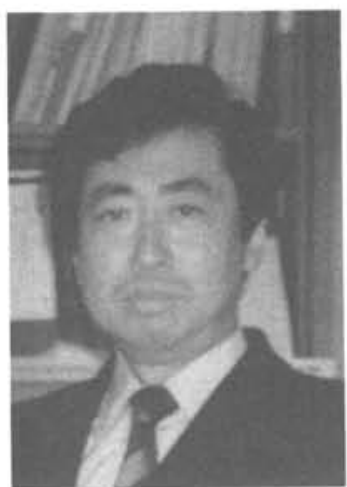

Dr. Asahiko Taira is a Professor of Marine Geology at Ocean Research Institute, University of Tokyo. He obtained his doctorate in geology from the University of Texas at Dallas (USA) in 1976. His research activities include the problems of sedimentation and tectonism in active plate margins. He worked at Kochi University, where he studied the Shimanto accretionary prism and tectonic evolution of Japan before he moved to Tokyo. Recently, he has been involved in various marine geological and geophysical investigations of active margins, especially the Nankai Trough.

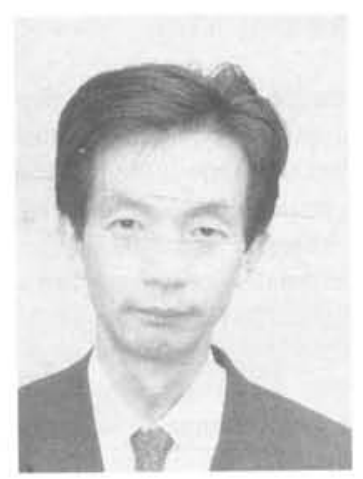

Dr. Yujiro Ogawa obtained his doctorate from the University of Tokyo in 1973, and he is a Professor of Geology at the University of Kyushu. He first studied the structural geology and tectonism of Mesozoic fold belts in southwestern Japan, and then he combined the marine and land geology from both sedimentary and structural viewpoints. He also has studied some basaltic and ophiolitic rocks in convergent boundaries by using ancient and current examples. His recent research activities include the tectonism of the Izu collision zone, the origin of mélanges, and the evolution of accretionary prisms. 